\title{
Restoration of a Temperate Reef: Effects on the Fish Community
}

\author{
Josianne Gatt Støttrup ${ }^{*}$, Claus Stenberg1, Karsten Dahl2 ${ }^{2}$, Louise Dahl Kristensen1, \\ Katherine Richardson ${ }^{3}$ \\ ${ }^{1}$ National Institute of Aquatic Resources, Technical University of Denmark, Charlottenlund, Denmark \\ ${ }^{2}$ Department of Bioscience, Aarhus University, Roskilde, Denmark \\ ${ }^{3}$ Center for Macroecology, Evolution and Climate, Natural History Museum of Denmark, University of \\ Copenhagen, Copenhagen, Denmark \\ Email: ${ }^{*}$ jgs@aqua.dtu.dk
}

Received 28 October 2014; revised 30 November 2014; accepted 15 December 2014

Academic Editor: Victor R. Savage, National University of Singapore, Singapore

Copyright (C) 2014 by authors and Scientific Research Publishing Inc.

This work is licensed under the Creative Commons Attribution International License (CC BY). http://creativecommons.org/licenses/by/4.0/

(c) (i) Open Access

\section{Abstract}

The extraction of large boulders from coastal reefs for construction of harbours and coastal protection has led to habitat degradation for local fish populations through the destruction of cavernous reefs and changes in macroalgal cover resulting from a loss of substrate. The temperate reef at Læsø Trindel in Kattegat, Denmark, has now been re-established with the aim of restoring the reef's historical structure and function. The effects of the restoration on the local fish community are reported here. Fishing surveys using gillnets and fyke nets were conducted before the restoration (2007) and four years after the restoration of the reef (2012). Species of the family Labridae, which have a high affinity for rocky reefs, dominated both before and after the restoration. Commercially important species such as cod Gadus morhua, and saithe Pollachius virens, occurred infrequently in the catches in 2007 but were significantly more abundant in the catches in 2012. Cods were especially attracted to the shallow part of the reef that was restored by adding stones. For some species, such as ballan wrasse Labrus bergylta, and cod, the proportion of larger individuals increased after the restoration. The findings highlight the importance of reef habitats for fish communities and the need for their protection.

\section{Keywords}

Reef Restoration, Impact Analysis, Labridae, Gadidae

\footnotetext{
${ }^{*}$ Corresponding author.
}

How to cite this paper: Støttrup, J.G., Stenberg, C., Dahl, K., Kristensen, L.D. and Richardson, K. (2014) Restoration of a Temperate Reef: Effects on the Fish Community. Open Journal of Ecology, 4, 1045-1059. 


\section{Introduction}

Marine reefs are important fish habitats providing complex structures that provide refuge for fish and hard substrate for benthic fauna and macroalgal forests that provide refuge and feeding sites for fish [1]-[3]. Reefs are listed in the EU Habitats Directive (1170 Reefs; Council Directive 92/43/EEC) and, for this reason, marine reefs in Danish waters have been designated as protected areas and are part of the EU-wide Natura2000 network indicating the acknowledged importance of this habitat type. Most of our knowledge on reef habitats is derived from studies on tropical reefs, although in the recent decade more focus has been directed towards the quantitative significance for fish communities of reef habitats in temperate areas. Most monitoring for fish assessment is limited to relatively smooth bottom areas due to the design of the survey gear [4]. Monitoring of fish communities on complex habitats such as temperate reefs and biogenic reefs are often limited to specific ecological studies of limited duration [5] [6]. Significantly higher catch rates of cod Gadus morhua on rough than on smooth bottom were suggested to be the main source for underestimation of the stock size of the North Sea cod [7]. Thus, limited temporal knowledge is available on the fish diversity and abundance in relation to temperate reefs and the quantitative ecological role of temperate reefs in our region.

Extensive mineral extraction of stones and boulders in coastal areas of Denmark [8] has not only led to destruction of cavernous reefs and removal of hard bottom but also removal of biogenic structures associated with these reefs and which are a main feature of temperate reefs [9]. The removal of larger boulders increases the average depth which may result in reduced benthic plant growth due to reduced light penetration with depth. A reduction of benthic plant growth reduces habitat complexity and reduces type and diversity of refugia for juvenile fish. The removal of the top stabilizing layer of larger boulders may also result in destabilization of the remaining reef, where smaller boulders or stones may be upturned in storms or strong current events with subsequent loss of perennial macrophytes and potential colonization of opportunistic macroalgal species. In Denmark, mineral extraction of large stones has now ceased but the consequences of the historical removal of material and destruction of these habitat types for fish populations are largely un-documented. No archives are available on the magnitude or precise geographic locations of the extractions.

The reef at Læsø Trindel, north-east of the island Læsø in Kattegat, Denmark (Figure 1(a)) was one of the many reef areas where mineral extractions took place during a period in the last century [8]. Archival maps showed the shallowest part of the reef to be $1.25 \mathrm{~m}$ below the surface in 1831 . The depth increased to $2.2 \mathrm{~m}$ in 1930 and to $\sim 4 \mathrm{~m}$ in the 1970s [10]. No information is available on how many boulders were mined from this reef complex. The macroalgal vegetation at this site was included in the National Marine Monitoring Program in 1991 and the results of the monitoring showed that the status of the reef was not in a Good Environmental State mainly due to the high dominance of opportunistic species at the expense of perennial species, compared to other sites in the monitoring program [11].

Species of the Labridae family are likely to be most affected by loss of reef habitats because of their high affinity to these habitat types and their complete dependence on this substrate for recruitment [12]. In fact, these authors suggested that a good indicator for the status of this habitat type might be the abundance of Labridae species or proportion of larger fish of Labridae as they depend on this substrate for reproduction. These species are, however, of no commercial value and are, therefore, not monitored. Thus, changes in their abundance or distribution may go undetected. In rocky habitats, species of Labridae also serve as prey for commercially important piscivors such as cod, mackerel Scombrus scombrus, saithe Pollachius virens, and whiting Merlangius merlangus that rely on teleosts as a major food source [13]. Thus, loss or degradation of rocky habitats may result in changes in trophic dynamics and impact trophic integrity in and around these habitat types. In recent decades, habitat restoration has expanded from terrestrial areas to the aquatic environment. In the aquatic environment, focus has been on freshwater systems (e.g. [14]). Restoration efforts in the marine environment are diverse, most of which have focused on restoring coral reefs [15], or large structural elements such as planting vegetation [16], restoring mangroves [17] and oyster reefs [18]. Unlike impacts from other human activity such as eutrophication and fishing, where the removal of the cause of the impact may lead to system recovery, reef habitats cannot be expected to recover without human intervention. The restoration of the marine temperate reef at Læsø Trindel (Kattegat, Denmark) represents one such large-scale intervention in European waters to restore a degraded natural reef. To our knowledge, this study represents the first temperate reef restoration in European waters. Although we have no details on the original form of the reef, we can use "before" and "after" restoration studies of biodiversity distributions on the reef to infer how reef damage affects ecosystems. In this study, the 


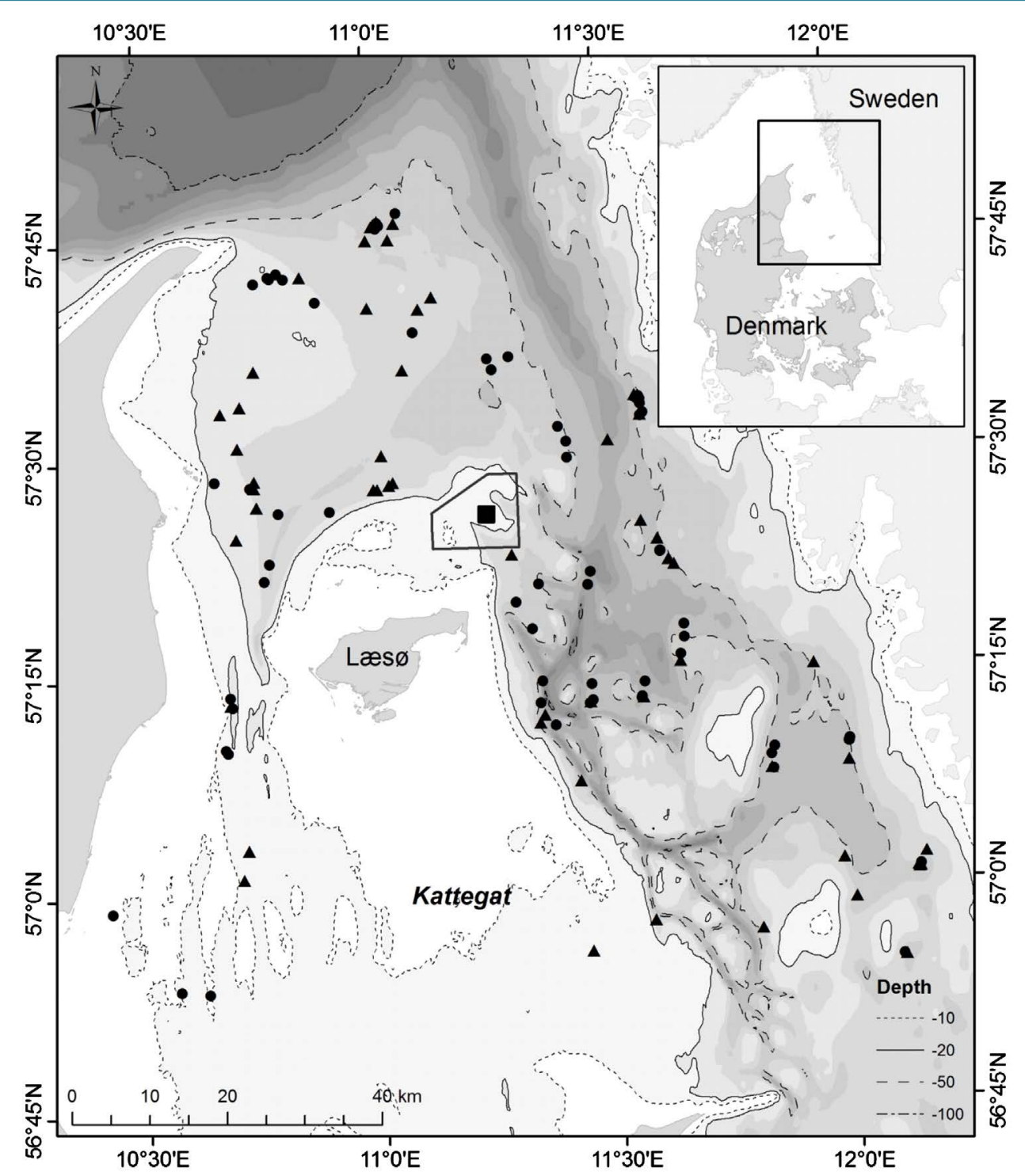

(a)

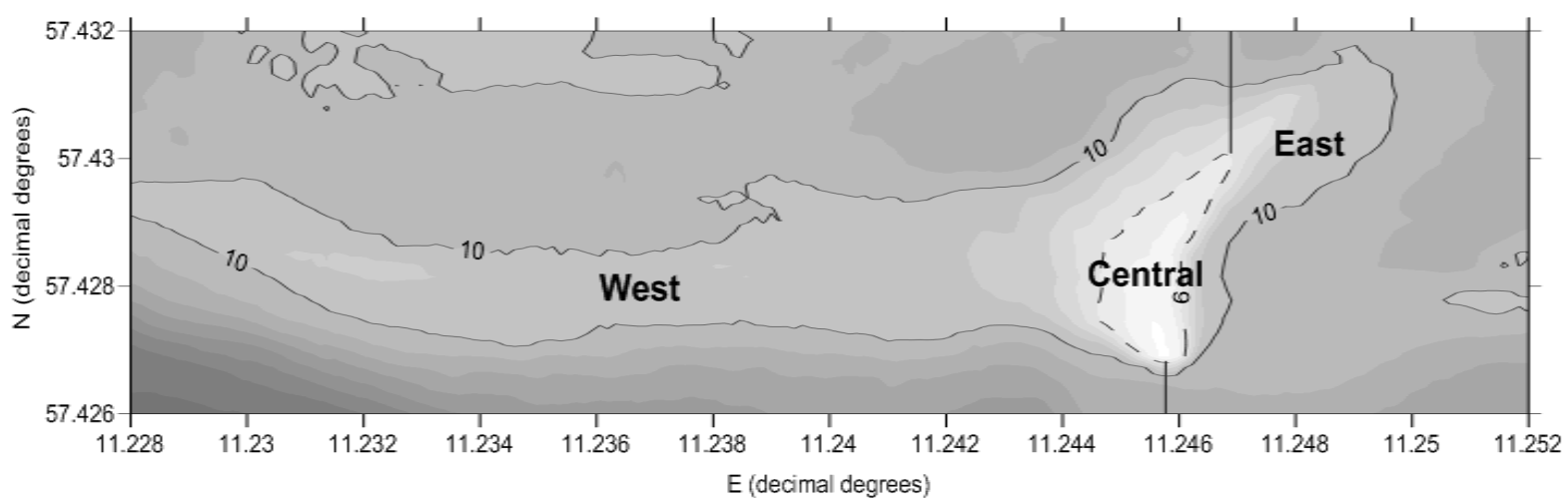

(b)

Figure 1. (a), (b) Map of the location of the reef at Læsø Trindel (black square, Figure 1(a)) within the NATURA 2000 site in the Kattegat (black border). Black circles (2005-2007; BEFORE) and triangles (2010-2012; AFTER) mark the positions of the stations from the research trawl surveys within $50 \mathrm{~km}$ of the reef site. Figure 1(b) shows the actual reef studied with 6 and $10 \mathrm{~m}$ depth contours and the location of the three sampling areas. 
damaged reef was restored to its former function in 2008 to serve as substrate for larger kelp-forming algae.

The aim of this study was to examine whether effects of restoring the boulder reef could be identified for the associated fish community. Effects on bottom fauna and flora of the reef restoration are presented elsewhere [10]. We hypothesized that the reef after restoration would provide more refugia and higher prey abundance than prior to restoration and that this would favor a higher abundance of reef fishes, a higher species richness and broader size distribution of fish.

\section{Materials and Methods}

\subsection{Study Site and Reef Restoration}

The reef at Læsø Trindel is located about $12 \mathrm{~km}$ north-east of the island of Læsø in the Kattegat (Figure 1(a)). The reef was stabilized with a layer of large boulders ranging in individual weight from $1600 \mathrm{~kg}$ to $3300 \mathrm{~kg}$ and parts of the central reef area were restored to its original depth during 2008 (Figure 1(b); [19]). A total of $\sim 100,000$ tons of boulders originating from Norway were deployed, covering an area of $\sim 27,600 \mathrm{~m}^{2}$ distributed in the depth range of $4-10 \mathrm{~m}$.

\subsection{Sampling}

The monitoring program was based on a "Before-After" approach. Due to economic constraints only one sampling was conducted before deployment of the reef in June 2007, and one sampling four years after deployment in June 2012. The sampling was a random stratified design. The area on Læsø Trindel was stratified into the areas; the central shallow part of the reef at 2 - $6 \mathrm{~m}$ depth, the western central part at $6-10 \mathrm{~m}$ depth; the eastern central part also at 6 - $10 \mathrm{~m}$ depth, and the surrounding area shallower than $10 \mathrm{~m}$ (Figure 1(b)). Although the depth contours had changed in the area of the restored reef [19], the area stratifications were maintained within the three areas. Fish abundance was surveyed with multi-meshed gillnets [20] and fyke nets. The mesh sizes in the multi-meshed gillnets were 11, 14, 19, 24, 31, 41, 53 and $70 \mathrm{~mm}$. Each panel was $1.5 \mathrm{~m}$ high and $6 \mathrm{~m}$ in length, except for the 53 and $70 \mathrm{~mm}$ panels which were, respectively, $12 \mathrm{~m}$ and $52 \mathrm{~m}$ long. Each gillnet had a random combination of panels, separated from each other by $1.8 \mathrm{~m}$ (float and sink line). The gillnets were deployed in the afternoon or evening and retrieved the following morning resulting in $\sim 12 \mathrm{~h}$ fishing time. The fyke nets had a mesh size of $18 \mathrm{~mm}$ and were $42 \mathrm{~cm}$ in height with a $6.5 \mathrm{~m}$ leader. Five fyke nets were mounted together in a row. These were deployed in the afternoon and fished $\sim 48 \mathrm{~h}$. In 2007, 4 replicates were made in each sampling site with gillnets and 7 - 9 replicates with fyke nets. In 2012, 4 - 11 replicates were made with gillnets and 2 - 4 replicates with fyke nets. Catches were identified to species and total length of each fish measured to the nearest lower $0.5 \mathrm{~cm}$ and weighed. For gillnets, catch per unit effort (CPUE) was standardized as catch in numbers per species or group per gillnet length in all the combined mesh size panels in the gillnet deployment. For fyke nets, CPUE was standardized as total catch in numbers per species or group for each deployment of the combined five fyke nets.

As we had no control area for monitoring, due to economic constraints, we chose to compare the development in cod abundance BEFORE and AFTER on Læsø Trindel with CPUE data from research trawl surveys in the neighboring area (Figure 1(a)). The CPUE provides an index where it is possible to observe positive or negative changes in abundance for each gear type. The trawl surveys are conducted by DTU Aqua in spring and autumn each year. The data from these surveys is also used in stock assessment of cod in the Kattegat in ICES where additional information on the surveys can be found (e.g. [21]). We included data within a distance of $50 \mathrm{~km}$ to Læsø Trindel and CPUE was divided into cod smaller or larger than $30 \mathrm{~cm}$ total length, and two periods representing the periods BEFORE (year 2005-2007) and AFTER (year 2010-2012). The stations for the trawl sampling are shown in Figure 1(a).

\subsection{Data Analyses and Statistics}

The effect of the reef restoration on fish abundance was analyzed for each group or species of fish by analyzing for the effect of BEFORE (year 2007)/AFTER (year 2012) in ANOVAs using the GLM procedure in SAS software 9.4. Copyright, SAS Institute Inc. Model residuals were tested for normal distribution by the Anderson-Darling test in the UNIVARIATE procedure in SAS. Fish were grouped into four categories "Gadidae", "Labridae", "Pleuornectiformes" and "Other" for the remaining fish species. Catch numbers were $+1 \log$ trans- 
formed prior to the statistical tests. Post-Hoc comparisons were performed with Tukey’s Studentized Range (HSD) test.

Species diversity was calculated using Shannon's $H$ index

$$
H=\sum p i^{*} \ln p i
$$

and Shannon's equitability index $E$

$$
E_{H}=H / \ln S
$$

where $p_{i}$ is the proportion of species $i$ to the total number of all species and $S$ is the total number of species.

Changes in abundance of cod of different size classes $(<20 \mathrm{~cm}, 20-30 \mathrm{~cm},>30 \mathrm{~cm})$ in the area around Læsø Trindel in the BEFORE/AFTER period were examined by an ANOVA on the negative binomial distributed CPUE data from the DTU Aqua research trawl surveys by the procedure COUNTREG in SAS. A similar analysis was conducted for changes in abundance of cod caught in the gillnets in the three reef sampling areas. Test statistics for the residual test are not shown unless the test was statistically significant. A significance level (p) of 0.05 was applied to all tests.

\section{Results}

The total number of species caught in 2007 in the combined catches of both gear types was 33 while a total of 30 species was caught in 2012. The number of species caught in the gillnets was 27 and was similar BEFORE and AFTER the restoration, whereas the number of species caught in the fyke nets was lower following restoration: 25 BEFORE decreasing to 21 AFTER (Table 1). Before the restoration, goldsinny wrasse Ctenolabrus rupestris, corkwing Symphodus melops, and small-mouthed wrasse Centrolabrus exoletus, comprised 78\% of the gillnet catches and ballan wrasse Labrus bergylta, corkwing and sole Solea solea, 64\% of the fyke net catches. After the restoration, the wrasses still dominated the catches but constituted $68 \%$ of the total catch. In the fyke nets, the Labridae were no longer dominant in 2012 and the catch was more evenly distributed among the groups. Thus, both Shannon's diversity index and equitability index tended to be slightly higher after the restoration, re- flecting the more even distribution of the individual species in the community AFTER the restoration than BEFORE.

The gadoids caught in the gillnets constituted mainly of cod, saithe and some whiting and Pollack Pollachius pollachius (Table 2). Abundance of gadoids was generally low in all parts of the reef BEFORE the restoration but increased significantly AFTER for all areas (Figure 2(a)) (ANOVA, p $<0.001$ ). Abundance increased particularly in the central part of the restored reef at $2-6 \mathrm{~m}$ depth. Here, abundance was significantly higher (Tukey, $\mathrm{p}<0.05)$ than over the western and eastern deeper $(6-10 \mathrm{~m})$ parts of the reef. The eastern and western parts of the reef were not significantly different from each other with respect to abundance neither BEFORE nor AFTER (Tukey, p > 0.05).

Table 1. Number of species caught in gillnets and fyke nets in 2007 and 2012. For each year and gear the frequency of catches of the different groups of fish species relative to total catch, Shannon's diversity index $H$ and equitability index $E_{H}$ calculated using catch per unit effort.

\begin{tabular}{ccccc}
\hline & \multicolumn{3}{c}{ Gillnets } & \multicolumn{2}{c}{ Fyke nets } \\
\cline { 2 - 5 } & 2007 & 2012 & 2007 & 2012 \\
Freq. Gadidae & 27.00 & 27.00 & 25.00 & 21.00 \\
Freq. Labridae & 0.02 & 0.13 & 0.001 & 0.20 \\
Freq. Pleuornectiformes & 0.87 & 0.68 & 0.654 & 0.25 \\
Freq. Other & 0.06 & 0.09 & 0.235 & 0.30 \\
$H$ & 0.05 & 0.10 & 0.110 & 0.26 \\
$E_{H}$ & 1.81 & 1.96 & 2.09 & 2.48 \\
& 0.55 & 0.59 & 0.65 & 0.82 \\
\hline
\end{tabular}


Table 2. Catch per unit effort for each fish species caught in gillnetsand fyke nets.

\begin{tabular}{|c|c|c|c|c|c|}
\hline \multirow[b]{2}{*}{ Latin name } & \multirow[b]{2}{*}{ English name } & \multicolumn{2}{|c|}{ Gillnets } & \multicolumn{2}{|c|}{ Fyke nets } \\
\hline & & 2007 & 2012 & 2007 & 2012 \\
\hline \multicolumn{6}{|l|}{ Gadidae } \\
\hline Gadus morhua & Cod & 4.50 & 13.40 & 0.22 & 11.00 \\
\hline Pollachius virens & Saithe & 0.40 & 3.52 & 0.00 & 0.67 \\
\hline Pollachius pollachius & Pollack & 0.40 & 0.76 & 0.00 & 0.00 \\
\hline Merlangius merlangus & Whiting & 0.30 & 0.04 & 0.00 & 0.00 \\
\hline \multicolumn{6}{|l|}{ Labridae } \\
\hline Labrus bergylta & Ballan wrasse & 19.80 & 2.32 & 20.11 & 0.00 \\
\hline Labrus bimaculatus & Cuckoo wrasse & 4.50 & 0.16 & 0.11 & 0.00 \\
\hline Ctenolabrus rupestris & Goldsinny wrasse & 29.50 & 59.80 & 8.11 & 8.44 \\
\hline Symphodus melops & Corkwing & 81.00 & 23.24 & 61.89 & 6.33 \\
\hline Centrolabrus exoletus & Small-mouthed wrasse & 98.70 & 7.04 & 15.33 & 0.11 \\
\hline \multicolumn{6}{|l|}{ Pleuronectiformes } \\
\hline Limanda limanda & Common dab & 9.60 & 6.52 & 11.22 & 6.22 \\
\hline Psetta maxima & Turbot & 1.30 & 0.04 & 0.11 & 0.00 \\
\hline Pleuronectes platessa & Plaice & 0.90 & 3.24 & 1.56 & 0.89 \\
\hline Microstomus kitt & Lemon sole & 0.50 & 0.44 & 2.89 & 3.78 \\
\hline Platichthys flesus & Flounder & 0.00 & 0.04 & 0.11 & 0.00 \\
\hline Scophthalmus rhombus & Brill & 0.80 & 0.24 & 0.89 & 0.33 \\
\hline Lepidorhombus whiffiagonis & Megrim & 0.00 & 0.00 & 0.11 & 0.00 \\
\hline Solea solea & Sole & 3.20 & 1.28 & 21.00 & 6.33 \\
\hline Arnoglossus laterna & Scaldfish & 0.00 & 0.04 & 0.00 & 0.00 \\
\hline Zeugopterus punctatus & Topknot & 0.10 & 0.00 & 0.00 & 0.11 \\
\hline \multicolumn{6}{|l|}{ Other } \\
\hline Icelus bicornis & Twohorn sculpin & 2.30 & 0.00 & 1.00 & 0.00 \\
\hline Trachinus draco & Greater weever fish & 4.30 & 3.40 & 0.22 & 0.22 \\
\hline Callionymus lyra & Common dragonet & 1.50 & 3.80 & 0.78 & 1.78 \\
\hline Ciliata mustella & Five-bearded rockling & 0.00 & 0.04 & 0.00 & 0.00 \\
\hline Enchelyopus cimbrius & Four-bearded rockling & 0.00 & 0.00 & 1.56 & 1.56 \\
\hline Belone belone & Garfish & 0.00 & 0.12 & 0.00 & 0.11 \\
\hline Entelurus aequoreus & Snake pipefish & 0.00 & 0.00 & 0.33 & 0.00 \\
\hline Cyclopterus lumpus & Lumpfish & 0.10 & 0.00 & 0.00 & 0.00 \\
\hline Clupea harengus & Herring & 0.90 & 0.00 & 0.00 & 0.00 \\
\hline Spinachia spinachia & Ten-spined stickleback & 0.10 & 0.60 & 1.11 & 0.11 \\
\hline Pholis gunnellus & Butter fish & 0.10 & 0.36 & 0.56 & 0.44 \\
\hline Hyperoplus lanceolatus & Greater sandeel & 0.10 & 0.00 & 0.00 & 0.00 \\
\hline Myoxocephalus scorpius & Sculpin & 2.80 & 3.16 & 3.00 & 2.89 \\
\hline Taurulus bubalis & Sea scorpion & 0.00 & 1.60 & 0.67 & 2.56 \\
\hline Anguilla anguilla & Eel & 0.00 & 0.00 & 4.78 & 1.44 \\
\hline Zoarces viviparus & Eelpout & 0.90 & 0.08 & 3.67 & 4.11 \\
\hline
\end{tabular}



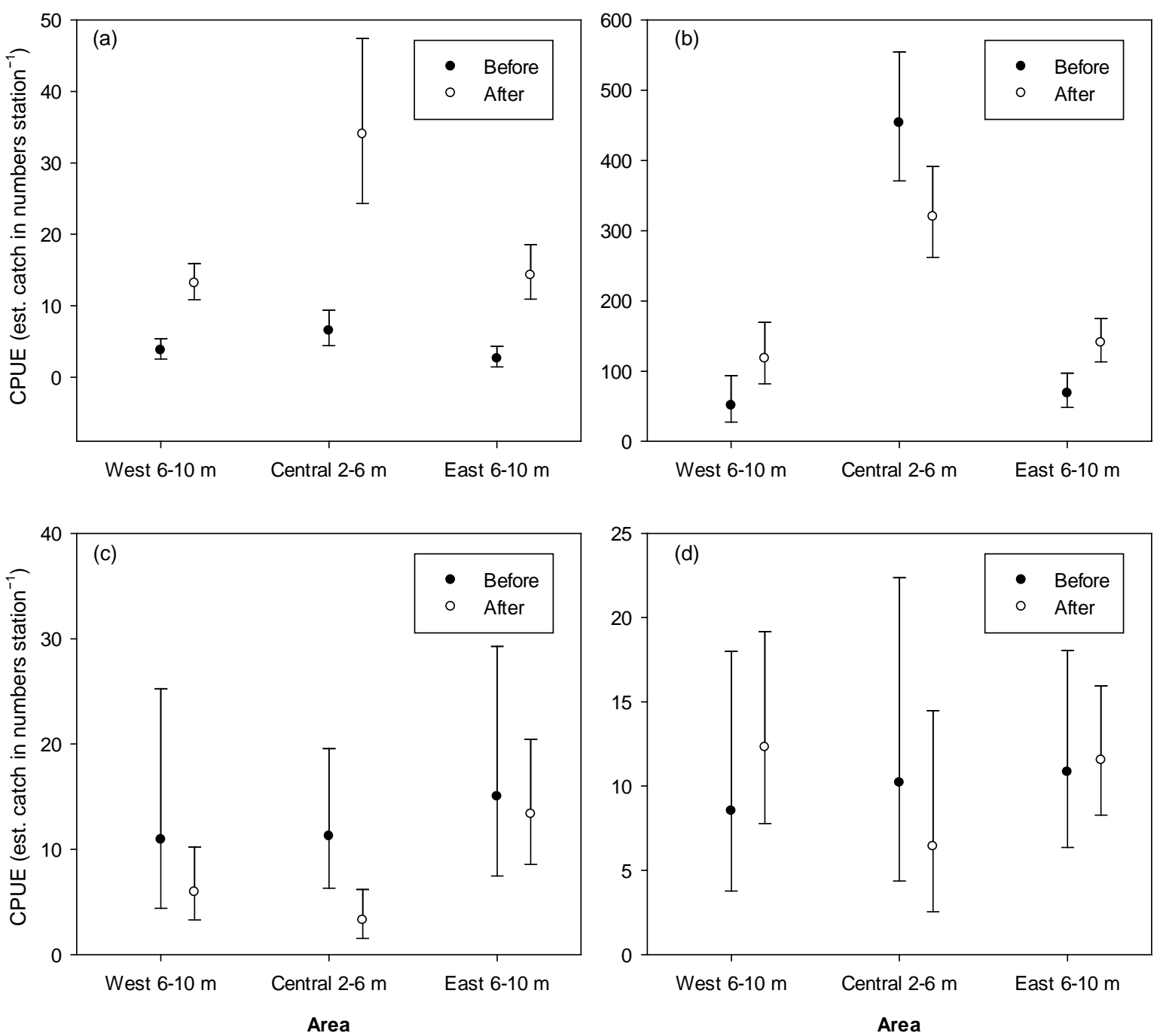

Figure 2. Catch per unit effort (CPUE) of fish caught with multi-meshed gillnets on Læsø Trindel. Estimated numbers + SE. BEFORE = 2007, AFTER = 2012. (a) Gadidae; (b) Labridae; (c) Pleuronectiformes; (d) Other.

Five species of Labridae were caught in gillnets in this study (Table 2). The highest abundances of these species were observed in the central shallow (2 - $6 \mathrm{~m}$ ) part of the reef both BEFORE and AFTER the restoration (Figure 2(b)). However, in the BEFORE situation, the difference between the areas was more pronounced, with significantly higher abundance in the central shallow $(2-6 \mathrm{~m})$ compared to the two deeper areas (Tukey, $\mathrm{p}>$ 0.005). The abundance of Labridae in the central shallow part of the reef decreased after the restoration, although the change was not significant (ANOVA, $p=0.0585)$. In the deeper part $(6-10 \mathrm{~m}$ ), the abundances of representatives from this group increased in both the deeper western part (ANOVA, $p=0.0419$ ) and the eastern part $(p=0.0058)$. While goldsinny wrasse increased in abundance AFTER the reef restoration, the other four species of Labridae decreased in abundance following restoration of the reef (Table 2).

Nine species of flatfish (Pleuronectiformes) were caught in the reef area with gillnets, most commonly dab Limanda limanda, and sole (Table 2). Abundance of these species decreased slightly after the restoration of the reef. The changes were not significantly different in the deeper western and eastern parts of the reef, but were significantly lower in the central shallow part $(\mathrm{p}=0.0344)$ (Figure 2(c)). In contrast to all the other flatfish species, plaice Pleuronectes platessa tended to increase in abundance after the reef restoration (Table 2).

The remaining fish species caught in gillnets were pooled into a group called "Other" (see list of species in Table 2). There were no differences in abundance of this "Other" group in any of the three areas of the reef from before and after the restoration (Figure 2(d)). 
Cod in fyke nets was the most frequently caught species (Table 2). The abundance of cod increased from 2007 to 2012 in all areas over the reef, although most notably in the shallow central part of the reef (West 6 - 10 $\mathrm{m}: \mathrm{p}=0.0069$; East $6-10 \mathrm{~m}: \mathrm{p}=0.0032$; Central $2-6 \mathrm{~m}: \mathrm{p}=0.0048$ ) (Figure 3(a)). Another gadoid species, the saithe, caught both BEFORE and AFTER the restoration was in the size range $18-26 \mathrm{~cm}$ and increased in abundance after the restoration (Table 2). In 2007, corkwing, ballan wrasse and small-mouthed wrasse were caught most frequently in fyke nets (Table 2). After the restoration, catches of all three species declined but the decline of wrasses caught in fyke nets was only significant in the eastern deeper part of the reef (East $6-10 \mathrm{~m}$ : $\mathrm{p}=0.0415$ ), while catches of goldsinny wrasse remained at the same level as BEFORE (Figure 3(b)). Flatfish catches tended to decline but this decline was not significant in any of the reef areas. The largest declines in catches were observed for dab and sole, which were the two most abundant flatfish in the 2007 catches (Figure 3(c); Table 2). Fish species from the "Other" group showed slightly higher catches after the restoration over the deeper eastern and western parts of the reef and lower in the central shallow part but the changes were not significant (Figure 3(d)).

The analyses of the size distribution of all fish caught in gillnets over the reef showed that numbers of fish $>30 \mathrm{~cm}$ tended to increase after the restoration (Figure 4). The size increase was mainly due to a higher occurrence of larger cod, which aggregated around the shallow part of the reef after the restoration (Figure 5(a)). The proportion of cod $>30 \mathrm{~cm}$ increased from 0.16 to 0.24 AFTER the restoration of the reef and the difference
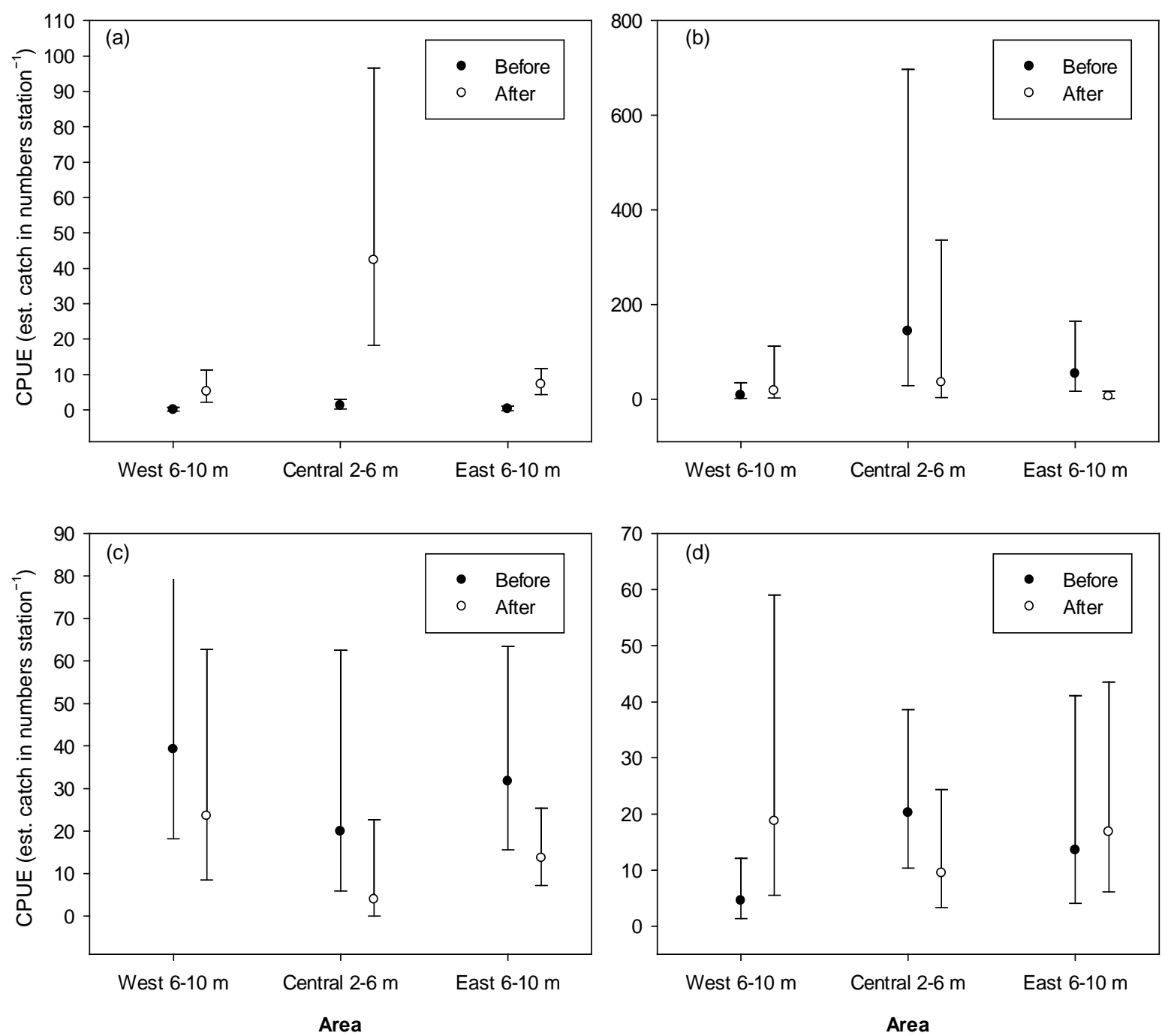

Figure 3. Catch per unit effort (CPUE) of fish caught with fykenets on Læsø Trindel. Estimated numbers + SE. BEFORE = 2007, AFTER = 2012. (a) Gadidae; (b) Labridae; (c) Pleuronectiformes; (d) Other. 


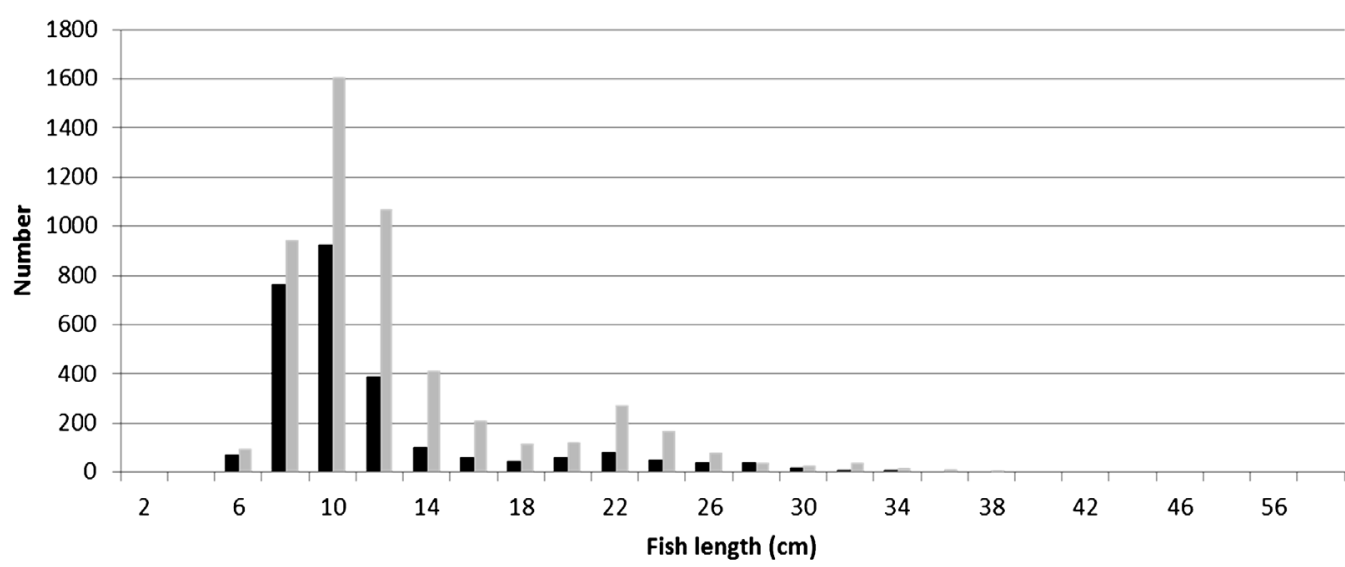

Figure 4. Length distribution of all fish caught in the multimesh gillnets BEFORE (black bars) and AFTER (light grey bars) the reef restoration.

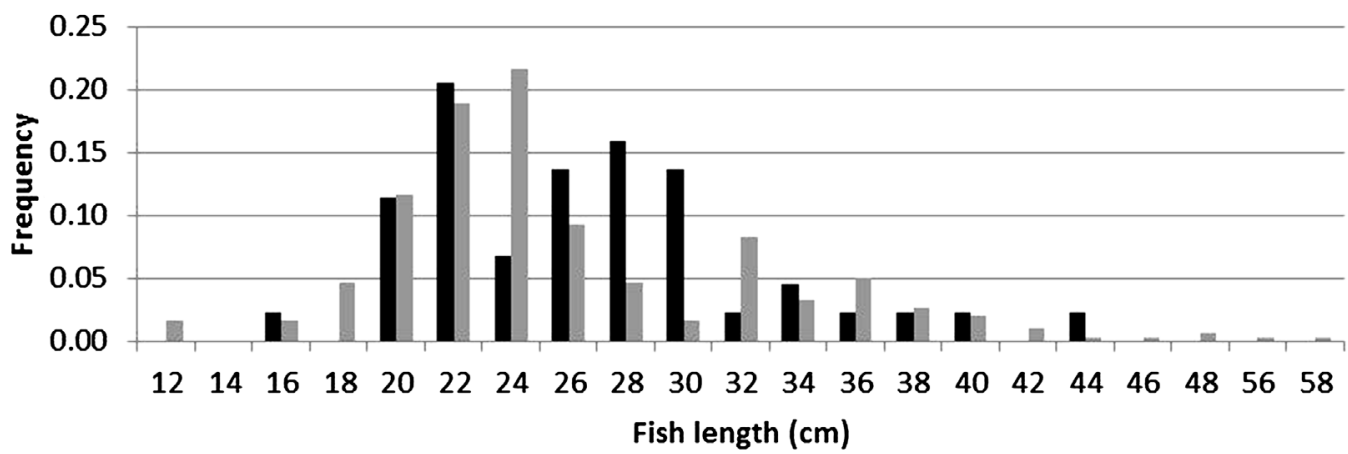

(a)

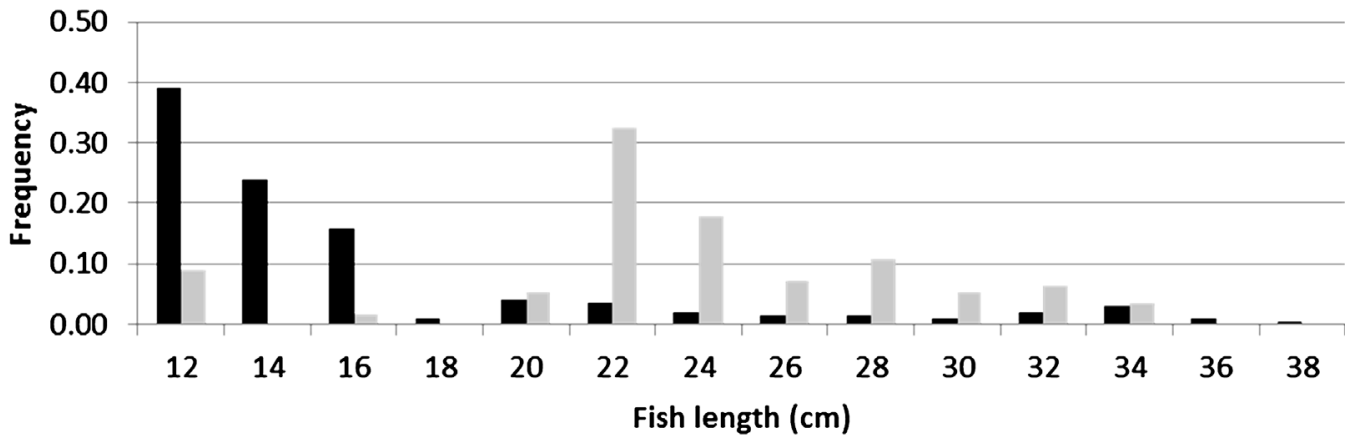

(b)

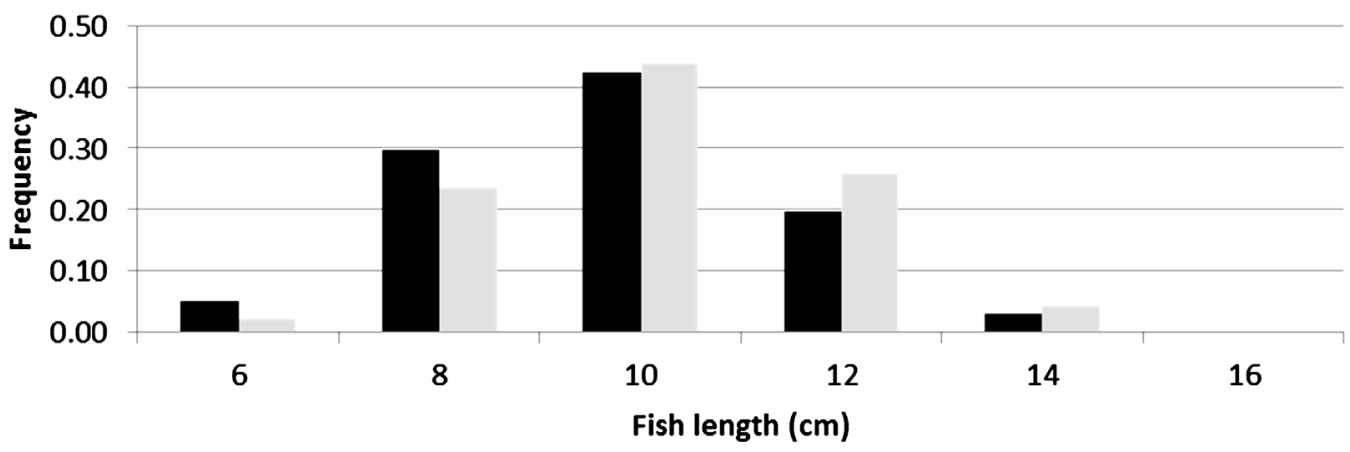

(c)

Figure 5. (a)-(c) Length frequency of cod (a), ballan wrasse (b) and goldsinny wrasse (c) caught in the multimesh gillnets BEFORE (black bars) and AFTER (light grey bars) the reef restoration. 
was statistically significant (ANOVA, $p=0.0004$ ). The abundance of juvenile cod also increased significantly after the restoration $(<20 \mathrm{~cm}$, ANOVA, $p<0.0001 ; 20-30 \mathrm{~cm}$, ANOVA, $\mathrm{p}=0.0001)$. Although abundance of ballan wrasse decreased after the restoration, those that were present AFTER the restoration were larger than BEFORE (Figure 5(b)). Goldsinny wrasse increased in abundance after the restoration with a slight shift towards larger individuals (Figure 5(c)).

Information from the research trawl surveys in the neighboring area showed that the abundance of cod $<20$ $\mathrm{cm}$ did not change significantly between the BEFORE and AFTER period (ANOVA, $p>0.55$ ) while cod from $20-30 \mathrm{~cm}$ (ANOVA, $\mathrm{p}<0.02$ ) and cod $>30 \mathrm{~cm}$ (ANOVA, $\mathrm{p}<0.001$ ) significantly declined from BEFORE to AFTER (Figure 6). Thus, the development with respect to the abundance and population structure for cod noted over the reef following restoration did not mirror the general development in the region as a whole.
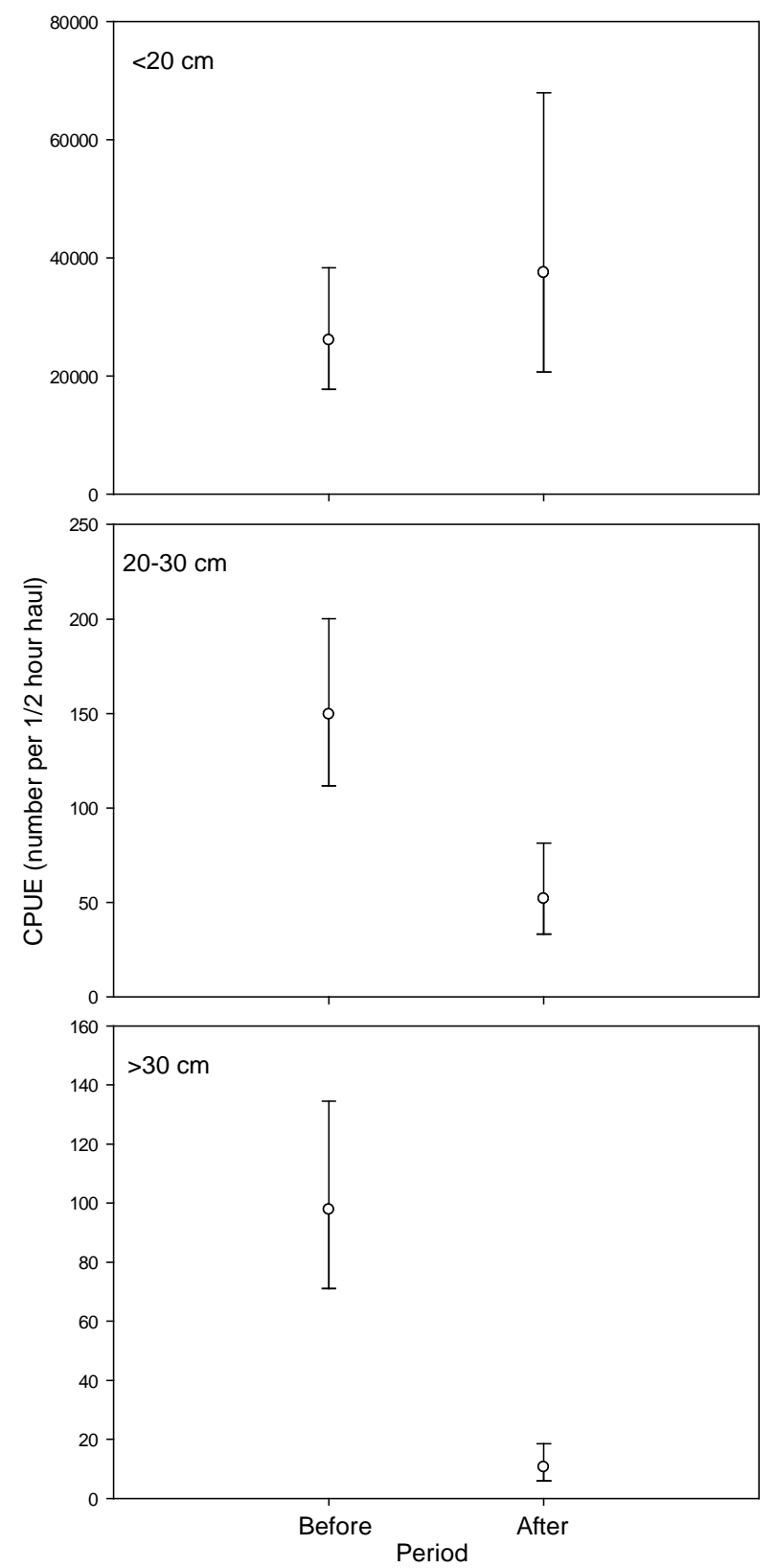

Figure 6. Catch per unit effort (CPUE) of cod in research trawl surveys within $50 \mathrm{~km}$ distance from Læsø Trindel. Estimated numbers + SE. BEFORE = years 2005-2007, AFTER = years 2010-2012. 


\section{Discussion}

This study demonstrates a change in fish diversity, the distribution of species and population size characteristics for some fish species from BEFORE and AFTER reef restoration. Results from this study presented elsewhere [10] [19] documented that the reef restoration led to a re-colonization of reef regions with macroalgae. Thus, we suggest that the changes noted in the fish populations here are likely related to the restoration of the reef habitat with macroalgal vegetation.

Much of our understanding of the importance of spatial heterogeneity and structure for recruitment of reef fishes derives from studies conducted on coral reefs. However, temperate reefs differ from coral reefs in that macroalgae dominate the physical structure of temperate reefs [9]. Thus, variability in abundance and type of macroalgae between and within reefs drive the dynamics of recruitment in temperate reef fishes [2] [6]. Destruction or degradation of temperate reef habitats leading to loss of large macroalgae and dominance of opportunistic algae results in loss of spatial heterogeneity and structure that appear to be important for recruitment in reef fishes as well as other demersal species that utilise complex hard bottom habitat.

The total number of species (32) caught with the multi-meshed gillnets over the two sampling years in this study was slightly lower than the number (38) reported by [5]. These authors used multi-meshed gillnets in a rocky-bottom coastal habitat on the west coast of Sweden, north-east of the study site of this study. The fyke nets caught a further four species including the European eel Anguilla anguilla, bringing the total number of species caught to 36. This indicates that the combination of multi-meshed gillnets and fyke nets used in this study was sufficient to sample a wide range of the species occurring in the area. Both gears used are selective. The high size selectivity of gillnets was taken into consideration with the multi-mesh gillnets, where a broad range of mesh sizes were used to ensure a wide size range of fish. As the aim of this work was to compare the fish assemblages BEFORE and AFTER the restoration, it was assumed that the bias in species capture and size range would be similar. However, the increased complexity of the restored reef, due to both a higher variety in relief but also the presence of larger algae, may have reduced the fishing efficiency of the nets, and the catches in the 2012 surveys may thus be underestimates.

The result that more complex habitats lead to higher species diversity and abundance than less complex ones is not unexpected and has been shown earlier for tropical and temperate marine habitats [22] [23]. In this study, however, we did not alter the habitat from a smooth bottom to a complex bottom, but rather attempted to increase the complexity by restoring the larger boulders, creating more relief and providing a physically stable substrate for the development of macroalgae [10]. The (Ash-Free Dry Weight) AFDWm ${ }^{-2}$ of the macroalgal biomass increased by more than twofold at 5 - $6 \mathrm{~m}$ depth and this was especially due to an increase in the brown algae (Phaeophyta) (Karsten Dahl, upublished data). Apparently, the increased complexity of the restored reef was not sufficient to result in a significant increase in fish species richness. In the general Kattegat area, a decline in sea bottom temperature of about $0.75^{\circ} \mathrm{C}$ between 2007 and 2011 was associated with a decline in species richness of 3 - 4 species per degree [24]. The decline in number of species in the fyke nets could, therefore, be due to this temperature decrease, but this does not explain the similar number of species in the gillnet catches in 2007 and 2012. The species decline in the fyke nets was driven by fewer flatfish species and the lack of ballan wrasse in the 2012 catches and may be due to a less favorable habitat for these species following reef restoration.

In this study, although species richness declined in the fyke net catches, Shannon's diversity index increased. The dominance of Labridae in the catches before the restoration decreased after the restoration resulting in a more even distribution of species especially in the fyke net catches. Abundance of the resident fish species, goldsinny wrasse tended to increase. Goldsinny wrasse is a resident species with high affinity to rocky substrate [25] [26]. Kelp forests, similar to that developed in the restored reef [10] provide ample feeding opportunities for this species [27]. Since refuge availability seems to be the main limiting factor determining the abundance of goldsinny wrasse [28], an increase in abundance of this species was expected. The larger labrid, the ballan wrasse, decreased in abundance AFTER but a higher proportion of larger fish inhabited the reef after the restoration than BEFORE. The ballan wrasse is a sedentary, territorial species with slow growth and it is a protogynous hermaphrodite [29]. The presence of larger sizes of fish is important in sex-changing fish species to maintain reproductive potential and population size [30]. Thus, the presence of larger specimens is important to secure sufficient sex ratios for effective mating. Due to the restricted home range of the species, even a small area with improved habitat and protected from fisheries would be sufficient for this and other Labridae species. The 
results suggest that the restored reef provided better opportunities for the larger fish predators and improved habitat for recruitment of wrasses, providing protection and potentially increasing the reproductive potential due to the increase in fish size.

The distribution of commercially important gadoids depends on the presence of heterogeneous substrate types and associated biogenic growth [31] [32]. Vegetated habitats, i.e. shallow rocky areas with algae and soft bottom sediment with seagrass beds, are important nursery areas for young juvenile cod [33]. In this study, the gadoids cod and saithe increased in abundance by a factor of $3-6$ after the restoration. Primarily the larger juveniles ( $>30$ and $>20 \mathrm{~cm}$ in length for cod and saithe, respectively) increased in abundance. The increase in abundance of juveniles in this study was not reflected in the bottom trawl surveys for the Kattegat stock component [21] [34], which show a negative trend. Furthermore, the analysis on the bottom trawl data performed in this study showed a marked decline in the abundance of larger juvenile cod in the area surrounding the reef (within $50 \mathrm{~km}$ ). These data were used in lieu of a lack of reference site for sampling before and after restoration and provide an opportunity to compare the development in abundances of different sizes of cod in the period before and after the reef restoration.

Notably, the shallow part of the reef (2 - $6 \mathrm{~m}$ ) attracted the highest abundance of cod AFTER the restoration. This is in line with the observations of [5], where the highest abundance of fish was found in shallow water (0 $3 \mathrm{~m}$ and $3-6 \mathrm{~m})$ kelp habitats and significantly lower abundance in the deeper $(6-10 \mathrm{~m})$ rocky habitat. The study of [5] was conducted in the Swedish archipelago north-east of the site of the reef restoration in this study. Juvenile cod are especially susceptible to limitations in demersal habitat due to their density-dependent mortality [35], suggesting a high vulnerability to the loss of complex habitats and the need to preserve these habitats for maintaining or rebuilding severely depleted stocks [36].

Fish densities are positively related to vegetation biomass [9] and the increased macroalgal biomass [10] was expected to increase fish densities in the restored area of the reef. The macroalgal dominance in temperate reefs may lead to high variability in fish assemblages and broader use of a reef habitat due to linkages between habitat attributes and life-stage strategies or behavioral responses in reef associated fishes [6]. Kelp forests, such as the one in the process of forming on the restored reef area [10], are known to be important feeding grounds for many fish species including cod [27].

Habitat degradation with loss of forest-forming macroalgae can be compared to kelp-harvest activity, except in the former case this impact is of a more permanent nature because before the reef stability or structure has been restored, macroalgae cannot re-establish. In newly-harvested kelp areas in Norway, the number of juvenile gadoids was 92\% lower than in un-harvested areas [32]. Lower abundances of gadoids persisted one year after the harvest. This is not unexpected considering gadoids utilize kelp forests as feeding and nursery areas and for shelter from larger predators [27]. Cod seek refuge in macroalgae to avoid predation in the presence of actively foraging predators [31], so juvenile cod tend to be segregated from larger cod [37]. In this study, the restoration of the reef resulted in higher abundances of juvenile cod $(<20 \mathrm{~cm})$ as well as a higher proportion of larger $(>30$ $\mathrm{cm}) \mathrm{cod}$ in the catches. The increased complexity of the restored reef habitat may, thus, have provided shelter and food for the smaller cod and better predation opportunities for the larger cod.

The increased proportion of larger cod, increased abundance of saithe, and increased proportion of larger specimens of the larger labrid, the ballan wrasse, in the restored reef area may reflect greater prey availability on the restored reef. The increased frequency of larger cod in the catches on the restored reef was in contrast to the decline of larger cod in the catches from the bottom trawl surveys in the area surrounding the restored reef. The generally higher frequencies of larger cod in our catches further reflect the affinity of larger cod to rocky substrate. The Kattegat cod stock is a unique population the Kattegat and has, since 2000, been considered outside safe biological limits by ICES [21]. Commercial fishing continues to take place and, accordingly, the reduction in reproductive capacity of this stock is considered to be due to reduced stock size rather than habitat loss [38]. The fishery in the area is dominated by trawls [21]; thus the restored reef where trawling is virtually impossible, could act as a refuge from fishing for the larger cod and contribute to the reproductive performance of the local population and, ultimately, recruitment.

Restoration is a rapidly developing field of research requiring clear objectives, appropriate definition of success criteria, and development of effective methodology to measure the success [39]. Most assessments focus on ecological attributes and although socio-economic attributes also should be targeted, it is important to measure the success of restoration to further this research field [39]. The restoration of the temperate reef in this study focused on ecological attributes; the results on the physical and social attributes will be addressed elsewhere. In 
this study we showed that the reef restoration brought about changes in the fish community. Dominance of wrasses was maintained after the restoration, but was less obvious than BEFORE the restoration due to the increased abundance of several other species resulting in a more even distribution of species. This suggests a higher variety of refuge and suitable micro-habitat types AFTER the restoration than BEFORE. Commercially important gadoid species, cod and saithe, increased 3 - 6-fold in abundance after the restoration. The restored shallow part of the reef seemed to particularly attract cod and goldsinny wrasse, although not significantly for the latter species. A higher proportion or larger specimens of cod and ballan wrasse after the restoration indicated improved foraging opportunity for the larger fish and an increase in the reproductive potential for these species. The concurrent increase in abundance of smaller cod $(<20 \mathrm{~cm})$ and higher proportion of larger cod (>30 $\mathrm{cm}$ ) indicated also an increase in refuge availability.

\section{Acknowledgements}

The project was funded by the EU LIFE project "Rebuilding of Marine Cavernous Boulder Reefs in Kattegat (Blue Reef)". LIFE06 NAT/DK/000159 and by the National Program for Coastal Recreational Fisheries "marinfiskepleje”.

\section{References}

[1] Graham, M.H. (2004) Effects of Local Deforestation on the Diversity and Structure of Southern California Giant Kelp Forest Food Webs. Ecosystems, 7, 341-357. http://dx.doi.org/10.1007/s10021-003-0245-6

[2] Christie, H., Jørgensen, N.M. and Norderhaug, K.M. (2007) Bushy or Smooth, High or Low; Importance of Habitat Architecture and Vertical Position for Distribution of Fauna on Kelp. Journal of Sea Research, 58, 198-208. http://dx.doi.org/10.1016/j.seares.2007.03.006

[3] Hunter, W.R. and Sayer, M.D.J. (2009) The Comparative Effects of Habitat Complexity on Faunal Assemblages of Northern Temperate Artificial and Natural Reefs. ICES Journal of Marine Science, 66, 691-698. http://dx.doi.org/10.1093/icesjms/fsp058

[4] ICES (2007) Report of the International Bottom Trawl Survey Working Group (IBTSWG). ICES CM 2007/RMC, 05:195 pp.

[5] Stål, J., Pihl, L. and Wennhage, H. (2007) Food Utilization by Coastal Fish Assemblages in Rocky and Soft Bottoms on the Swedish West Coast: Inference for Identification of Essential Fish Habitats. Estuarine, Coastal and Shelf Science, 71, 593-607. http://dx.doi.org/10.1016/j.ecss.2006.09.008

[6] Pérez-Matus, A. and Shima, J.S. (2010) Disentangling the Effects of Macroalgae on the Abundance of Temperate Reef Fishes. Journal of Experimental Marine Biology and Ecology, 388, 1-10. http://dx.doi.org/10.1016/j.jembe.2010.03.013

[7] Wieland, K., Pedersen, E.M.F., Olesen, H.J. and Beyer, J.E. (2009) Effect of Bottom Type on Catch Rates of North Sea Cod (Gadus morhua) in Surveys with Commercial Fishing Vessels. Fisheries Research, 96, 244-251. http://dx.doi.org/10.1016/j.fishres.2008.11.010

[8] Dahl, K., Lundsteen, S. and Helmig, S. (2003) Stenrev, Havbundens Oaser. Gads Forlag, Copenhagen, Denmark. (In Danish)

[9] Carr, M.H. (1994) Effects of Macroalgal Dynamics on Recruitment of a Temperate Reef Fish. Ecology, 75, $1320-1333$. http://dx.doi.org/10.2307/1937457

[10] Stenberg, C., Støttrup, J.G., Dahl, K., Lundsteen, S., Göke, C. and Andersen, O.N. (2013) Ecological Benefits from Restoring a Marine Cavernous Boulder Reef in Kattegat, Denmark. Final Report to the European Commission Regarding LIFE06 NAT/DK000159 Blue Reef, 47.

[11] Dahl, K., Stenberg, C., Lundsteen, S., Støttrup, J., Dolmer, P. and Tendal, O.S. (2009) Ecology of Læsø Trindel—A Reef Impacted by Extraction of Boulders. National Environmental Research Institute, Technical Report No. 757.

[12] Almada, V.C., Henriques, M. and Gonçalves, E.J. (1999) Ecology and Behaviour of Reef Fishes in the Temperate North-Eastern Atlantic and Adjacent Waters. In: Almada, V.C., Oliveira, R.F. and Gonçalves, E.J., Eds., Behaviour and Conservation of Littoral Fishes, ISPA, Lisbon, 33-68.

[13] Wennhage, H. and Pihl, L. (2002) Fish Feeding Guilds in Shallow Rocky and Soft Bottom Areas on the Swedish West Coast. Journal of Fish Biology, 61, 207-228. http://dx.doi.org/10.1111/j.1095-8649.2002.tb01772.x

[14] Swales, S. (1994) Habitat Restoration Methods-A Synthesis. In: Cowx, I.G., Ed., Rehabilitation of Freshwater Fisheries, Fishing News Books, Oxford, 133-137. 
[15] Rinkevich, B. (2014) Rebuilding Coral Reefs: Does Active Reef Restoration Lead to Sustainable Reefs? Current Opinion in Environmental Sustainability, 7, 28-36. http://dx.doi.org/10.1016/j.cosust.2013.11.018

[16] Chapman, M.G. (1999) Improving Sampling Designs for Measuring Restoration in Aquatic Habitats. Journal of Aquatic Ecosystem Stress and Recovery, 6, 235-251. http://dx.doi.org/10.1023/A:1009987403481

[17] Barbier, E. (2006) Natural Barriers to Natural Disasters: Replanting Mangroves after the Tsunami. Frontiers in Ecology and the Environment, 4, 124-131. http://dx.doi.org/10.1890/1540-9295(2006)004[0124:NBTNDR]2.0.CO;2

[18] Kennedy, V.S., Breitburg, D.L., Christman, M.C., Luckenbach, M.W., Paynter, K., Kramer, J., Sellner, K.G., DewBaxter, J., Keller, C. and Mann, R. (2011) Lessons Learned from Efforts to Restore Oyster Populations in Maryland and Virginia, 1990 to 2007. Journal of Shellfish Research, 30, 719-731. http://dx.doi.org/10.2983/035.030.0312

[19] Anonymous (2013) Post Bathymetry and Stability of Reef Structures. Technical Final Report LIFE06 NAT/DK/ 000159-Blue Reef, Annex 15, 5. http://naturstyrelsen.dk/naturbeskyttelse/naturprojekter/blue-reef/undersoegelser-investigations/

[20] Eigaard, O.R., Støttrup, J.G. and Hovgård, H. (2000) Udvikling af standard garnserie til brug ved rutinemæssig bestandsanalyse af flad-og rundfisk i marine lavvandede områder. DFU-Report nr. 78-00. (In Danish)

[21] ICES (2012) Report of the Baltic Fisheries Assessment Working Group 2012 (WGBFAS). ICES CM. 2012/ACOM: 10, 12-19 April 2012, ICES Headquarters, Copenhagen, 859 p.

[22] Jones, G.P. (1988) Ecology of Rocky Reef Fish of North-Eastern New Zealand: A Review. New Zealand Journal of Marine and Freshwater Research, 22, 445-462. http://dx.doi.org/10.1080/00288330.1988.9516315

[23] Gratwicke, B. and Speight, M.R. (2005) The Relationship between Fish Species Richness, Abundance and Habitat Complexity in a Range of Shallow Tropical Marine Habitats. Journal of Fish Biology, 66, 650-667. http://dx.doi.org/10.1111/j.0022-1112.2005.00629.x

[24] Bryndum, K.M. (2013) Fish Species Composition in the Inner Danish Waters. An Analysis of the Fish Assemblage in Light of Changes in Sea Temperature. Master’s Thesis, Center for Macroecology, Evolution and Climate, University of Copenhagen, Copenhagen.

[25] Sayer, M.D.J., Gibson, R.N. and Atkinson, R.J.A. (1993) Distribution and Density of Populations of Goldsinny Wrasse (Ctenolabrus rupestris) on the West Coast of Scotland. Journal of Fish Biology, 43, 157-167. http://dx.doi.org/10.1111/j.1095-8649.1993.tb01185.x

[26] Gjøsæter, J. (2002) Distribution and Density of Goldsinny Wrasse (Ctenolabrus rupestris) (Labridae) in the Risør and Arendal Areas along the Norwegian Skagerrak Coast. Sarsia, 87, 75-82. http://dx.doi.org/10.1080/003648202753631758

[27] Norderhaug, K.M., Christie, H., Fosså, J.H. and Fredriksen, S. (2005) Fish-Macrofauna Interactions in a Kelp (Laminaria hyperborea) Forest. Journal of the Marine Biological Association of the United Kingdom, 85, 1279-1286. http://dx.doi.org/10.1017/S0025315405012439

[28] Costello, M.J. (1991) Review of the Biology of Wrasse (Labridae: Pisces) in Northern Europe. Progress in Underwater Science, 16, 29-51.

[29] Villegas-Ríos, D., Alos, J. and March, D. (2013) Home Range and Diel Behavior of the Ballan Wrasse, Labrus bergylta, Determined by Acoustic Telemetry. Journal of Sea Research, 80, 61-71. http://dx.doi.org/10.1016/j.seares.2013.02.009

[30] Alonzo, S.H. and Mangel, M. (2004) The Effects of Size-Selective Fisheries on the Stock Dynamics of and Sperm Limitation in Sex-Changing Fish. Fisheries Bulletin, 102, 1-13.

[31] Gotceitas, V., Fraser, S. and Brown, J.A. (1995) Habitat Use by Juvenile Atlantic Cod (Gadus morhua) in the Presence of an Actively Foraging and Nonforaging Predator. Marine Biology, 123, 421-430. http://dx.doi.org/10.1007/BF00349220

[32] Lorentsen, S.H., Sjøtun, K. and Grémillet, D. (2010) Multi-Trophic Consequences of Kelp Harvest. Biological Conservation, 143, 2054-2062. http://dx.doi.org/10.1016/j.biocon.2010.05.013

[33] Stål, J., Paulsen, S., Pihl, L., Rönnbäck, P., Söderqvist, T. and Wennhage, H. (2008) Coastal Habitat Support to Fish and Fisheries in Sweden: Integrating Ecosystem Functions into Fisheries Management. Ocean \& Coastal Management, 51, 594-600. http://dx.doi.org/10.1016/j.ocecoaman.2008.06.006

[34] Vinther, M. and Eero, M. (2013) Quantifying Relative Fishing Impact on Fish Populations Based on Spatio-Temporal Overlap of Fishing Effort and Stock Density. ICES Journal of Marine Science, 70, 618-627. http://dx.doi.org/10.1093/icesjms/fst001

[35] Meyers, R.A. and Cadigan, N.G. (1993) Density-Dependent Juvenile Mortality in Marine Demersal Fish. Canadian Journal of Fisheries and Aquatic Sciences, 50, 1576-1590. http://dx.doi.org/10.1139/f93-179

[36] Gregory, R.S. and Anderson, J.T. (1997) Substrate Selection and Use of Protective Cover by Juvenile Atlantic Cod 
Gadus morhua in Inshore Waters of Newfoundland. Marine Ecology Progress Series, 146, 9-20. http://dx.doi.org/10.3354/meps146009

[37] Fraser, S., Gotceitas, V. and Brown, J.A. (1995) Interactions between Age-Classes of Atlantic Cod and Their Distribution among Bottom Substrates. Canadian Journal of Fisheries and Aquatic Sciences, 53, 305-314. http://dx.doi.org/10.1139/f95-183

[38] Svedäng, H., Stål, J., Sterner, T. and Cardinale, M. (2010) Subpopulation Structure in Cod (Gadus morhua) Puts Strain on the Management Toolbox. Reviews in Fisheries Science, 18, 139-150. http://dx.doi.org/10.1080/10641260903511420

[39] Wortley, L., Hero, J.M. and Howes, M. (2013) Evaluating Ecological Restoration Success: A Review of the Literature. Restoration Ecology, 21, 537-543. http://dx.doi.org/10.1111/rec.12028 
Scientific Research Publishing (SCIRP) is one of the largest Open Access journal publishers. It is currently publishing more than 200 open access, online, peer-reviewed journals covering a wide range of academic disciplines. SCIRP serves the worldwide academic communities and contributes to the progress and application of science with its publication.

Other selected journals from SCIRP are listed as below. Submit your manuscript to us via either submit@scirp.org or Online Submission Portal.
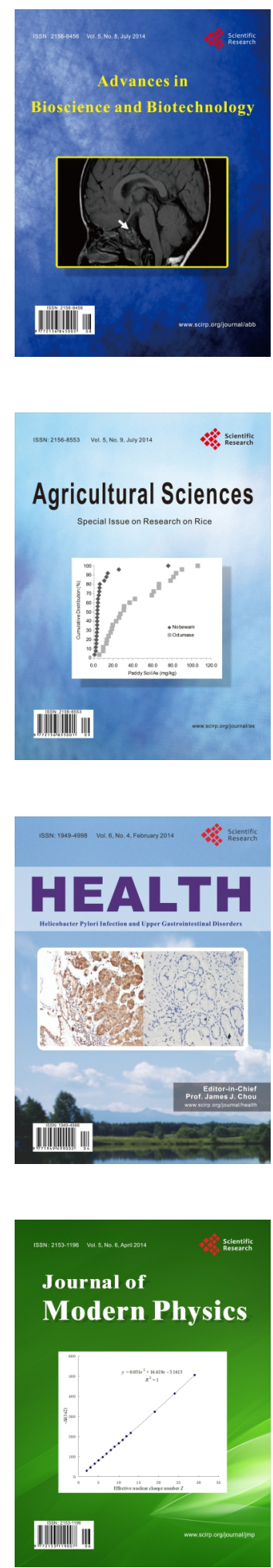
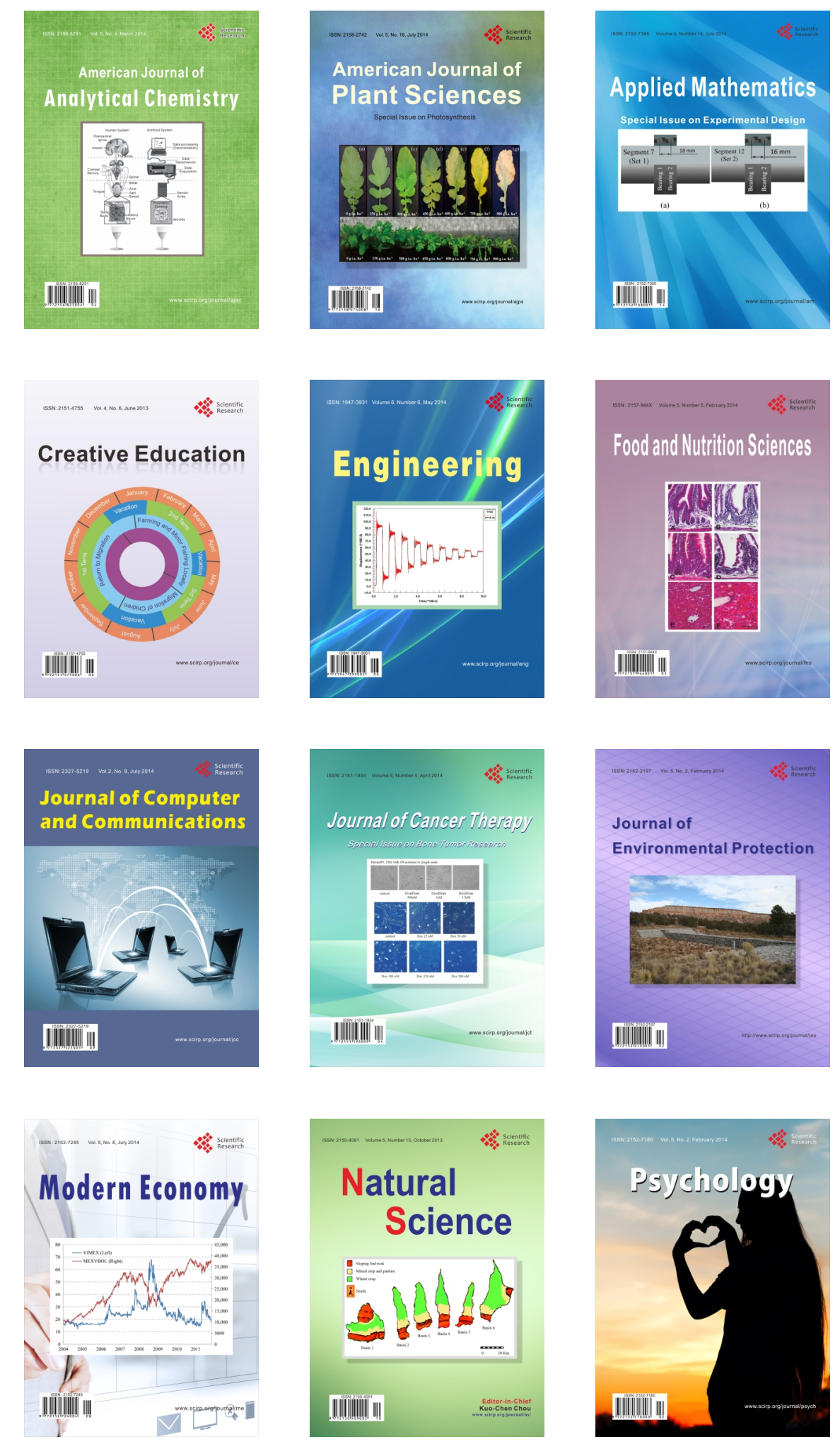